\title{
Neogene-Quaternary seismic stratigraphy of the Llancanelo Lake Basin, Mendoza, Argentina
}

\author{
*Luciano Onnis ${ }^{1}$, Roberto Antonio Violante ${ }^{2}$, Ana Osella ${ }^{1}$, Matías de la Vega ${ }^{1}$, \\ Alejandro Tassone ${ }^{3}$, Ernesto López ${ }^{1}$
}

\begin{abstract}
${ }^{I}$ Departamento de Física. Facultad de Ciencias Exactas y Naturales (FCEyN), Universidad de Buenos Aires, IFIBA-CONICET, Intendente Güiraldes 2160, Ciudad Universitaria, Pabellón I, Buenos Aires, Argentina. leonnis@df.uba.ar; osella@df.uba.ar;matias@df.uba.ar;.elopez@df.uba.ar

2 División Geología y Geofisica Marina, Servicio de Hidrografia Naval, Montes de Oca 2124, C1270ABV, Buenos Aires, Argentina. violante@hidro.gov.ar

3 Instituto de Geociencias Básicas, Aplicadas y Ambientales de Buenos Aires (IGeBA), Departamento de Ciencias Geológicas, FCEyN, Universidad de Buenos Aires, Intendente Güiraldes 2160, Ciudad Universitaria, Pabellón II, Buenos Aires, Argentina. atassone@gl.fcen.uba.ar
\end{abstract}

* Corresponding author: leonnis@df.uba.ar

\begin{abstract}
A new shallow multichannel seismic survey was carried out in the Llancanelo Lake region (Southern Mendoza Province, Argentina), in order to complete and extend previously surveyed seismic sections. The new seismic data allowed to double the already existing data. The obtained information was correlated with seismic and stratigraphic data from the industry. In this way it was possible to depict the major Neogene-Quaternary sedimentary-volcanic sequences and the regional evolution of a tectonic-volcanic basin located in a key region at the eastern foot of the Andes cordillera. This research is settled on early studies that comprised seismic works reaching depths of $600-700 \mathrm{~m}$ as well as geoelectric and electromagnetic surveys reaching the uppermost $80-100 \mathrm{~m}$ of the sequences. The obtained results indicate the presence of three major sedimentary units separated by conspicuous seismic horizons SR1, SR2 and SR3, respectively considered as representing the late Mesozoic transition from marine to continental deposition, the beginning of the Cenozoic basaltic volcanism, and the change from dominantly sedimentary to dominantly volcanic processes at the base of the Quaternary. The resulting stratigraphic scheme reveals increasing volcanic (basaltic layers) intercalations with depth that accommodate to the geometry of the depocenter.
\end{abstract}

Keywords: Neogene-Quaternary, Seismic stratigraphy, Shallow seismic, Llancanelo.

RESUMEN. Estratigrafía sísmica Neógeno-Cuaternaria de la Cuenca de la laguna de Llancanelo, Mendoza, Argentina. Un nuevo relevamiento de sísmica somera multicanal se llevó a cabo en la región de la laguna de Llancanelo (sur de la provincia de Mendoza, Argentina), para completar y extender secciones sísmicas adquiridas previamente. Los nuevos datos sísmicos permitieron duplicar la cantidad de datos existentes. La información obtenida fue correlacionada con datos sísmicos y estratigráficos de la industria. De esta manera fue posible describir las principales secuencias volcano-sedimentarias del Neógeno-Cuaternario y la evolución regional de una cuenca tectono-volcánica, ubicada en una región clave en el límite oriental de la cordillera de los Andes. Esta investigación se apoya en estudios anteriores que comprenden trabajo sísmicos con profundidades de hasta 600-700 m, así como también estudios geoeléctricos y electromagnéticos que alcanzan los primeros 80-100 m de las secuencias. Los resultados obtenidos indican la presencia de tres unidades sedimentarias principales separadas por horizontes sísmicos conspicuos SR1, SR2 y SR3, que respectivamente representan la transición de depositación marina a continental del Mesozoico tardío, el comienzo del volcanismo basáltico del Cenozoico, y el cambio de procesos dominantemente sedimentarios a dominantemente volcánicos en la base del Cuaternario. El esquema estratigráfico resultante revela intercalaciones volcánicas (capas basálticas) que aumentan con la profundidad y se acomodan a la geometría del depocentro. 


\section{Introduction}

The area of Llancanelo lake, southeast of Malargüe city, at the eastern foot of the Andes in the Province of Mendoza, central-western Argentina (Fig. 1a) is located in the southern tip of an intermountain sedimentary basin of tectonic origin (Tunuyán half graben) and in the northern part of a very extensive back-arc volcanic field (Payenia). The area represents a key location at the boundary between the three major geological provinces in the region, Main Cordillera, Payenia and Neuquén Basin, in a place very close to the north-western limit of Patagonia. This geotectonic framework conditioned the regional geological history and particularly the evolution of Llancanelo lake, which responded to a complex interaction among endogen (tectonism, volcanism) and exogenous (climate, sedimentary processes) factors. The lake constitutes a wetland which is considered as a Province Natural Reserve categorized as a Ramsar site. On the other hand, the basin, and particularly the lake surroundings, is an important hydrocarbon reservoir. Therefore, the knowledge of the geological and environmental characteristics of the area is relevant for the adequate management and conservation of this region.

The region was studied in the past by the oil industry using geological (deep drillings) and geophysical (deep seismic) methods with the aim of obtaining information useful to hydrocarbon exploration, and more recently several environmental studies have been carried out. Particularly in the last decade the research team which the authors of the present contribution belong to, conducted shallow and low- to middlepenetration geoelectric and shallow seismic studies. These studies, supported by surface and subsurface geological samplings (short hand-drillings) were applied for the first time in the study area with the objective of defining the Neogene-Quaternary succession of sedimentary and volcanic rock sequences and depicting the geological factors involved in the recent evolution of the region (Violante et al., 2010; De la Vega et al., 2012; Osella et al., 2015).

In this contribution, new seismic lines were performed along two transects surveyed north and west of the lake, in such a way that the area covered by the previous seismic surveys was in this case duplicated, which resulted in a much more complete covering and knowledge of the region. Additionally, the correlation of our seismic data with the deep geological and geophysical information obtained by the industry, allowed a much better understanding of the regional geological evolution, and also to fit the seismic-stratigraphic units into a chronostratigraphic scheme using the formal stratigraphic nomenclature known for the region as defined by Nullo et al. (2005).

\section{Regional geological framework and stratigraphy}

The area of Llancanelo is located at the southern extreme of a large tectonic basin ("Central Depression", Llambías et al., 2010) extended at the foot of the eastern side of the Main Cordillera (Fig. 1a). In the northern part, the Central Depression is part of the Tunuyán half-graben, whereas south of it the basin extends along the so called Central or Los Huarpes Depression. The basin containing the lake is defined as "Llancanelo sub-basin" (Llambías et al., 2010). The southern end of this depression is occupied by the Payenia Volcanic Field, which according to Bermúdez and Delpino (1989) comprises two volcanic fields, named Llancanelo and Payenia. The basin evolved under a dominant tectonic control of extensional character, and acquired its definitive configuration in the Quaternary (Polanski, 1963; Ramos, 1999; Cortés et al., 1999; Ramos and Folguera, 2005, 2011). The major regional tectonic evolution occurred in the Miocene. It resulted in the development of major faulting-thrust systems related to the evolution of the Malargüe Thrust and Fold Belt together with the San Rafael Block uplift, the formation of the Río Grande Foreland Basin and later on by the Tunuyán half-graben during the Late Pleistocene (Polanski, 1963; Ramos, 1999; Ramos and Folguera, 2005, 2011; Ramos and Key, 2009). The resulting features are deep faulting systems characterized by numerous normal faults that experienced successive reactivations along its history, even up to the Quaternary. Several authors such as Ramos (1999), Ramos and Folguera (2005, 2011) and Folguera et al. (2008) highlight the presence of a prominent north-south trending fault that bounds Llancanelo Lake on its east side, which according to them displays throws exceeding $700 \mathrm{~m}$ that affected up to the Pliocene sequences. The tectonic history conditioned the development of a Central Depression that was filled with sedimentary sequences, described as "deposits of piedmont plains and alluvial" with a thickness of up to few hundreds of meters (Nullo et al., 2005). According to Ostera and Dapeña (2003) the alluvial sequences have a thickness 


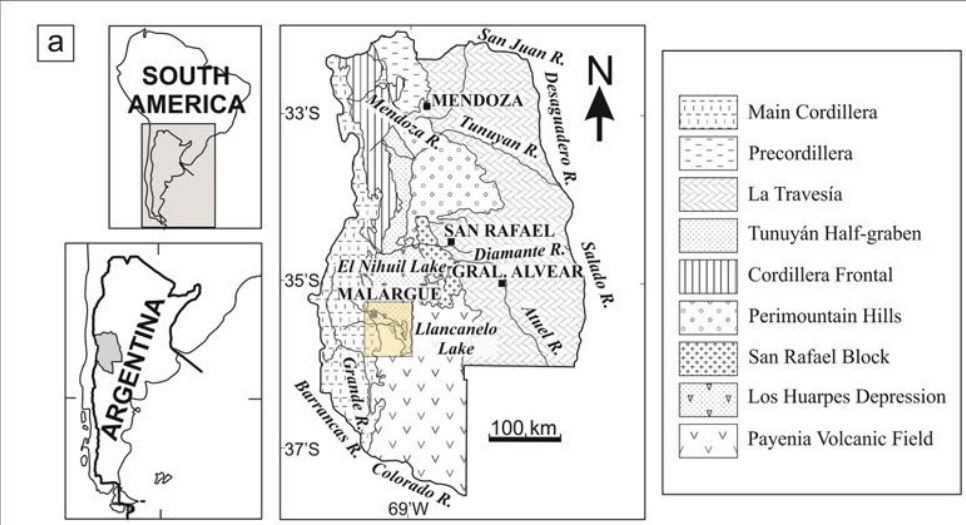

b

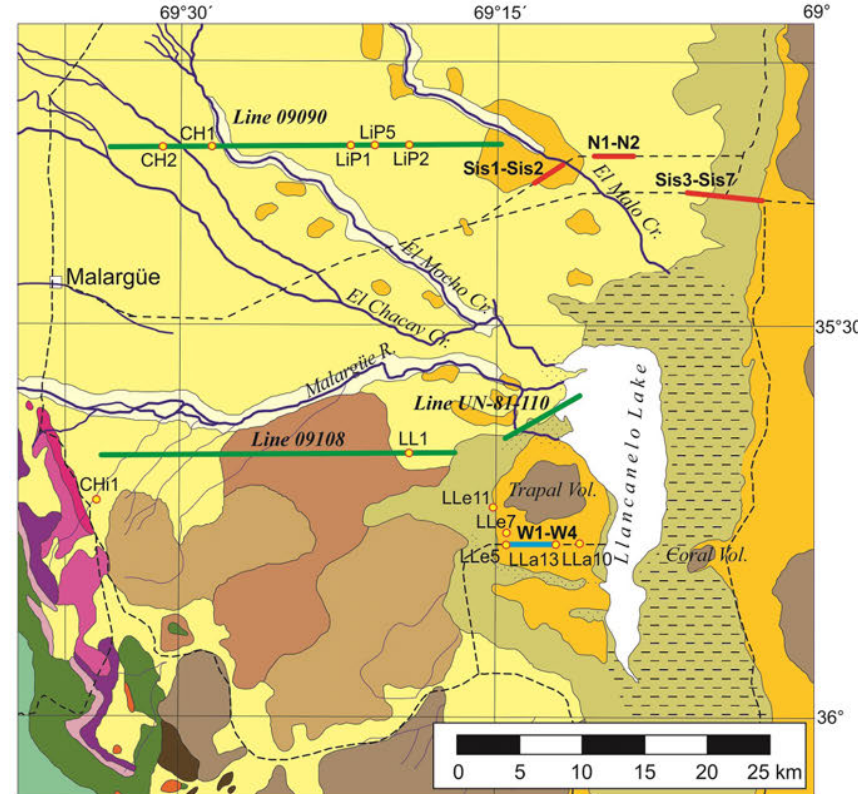

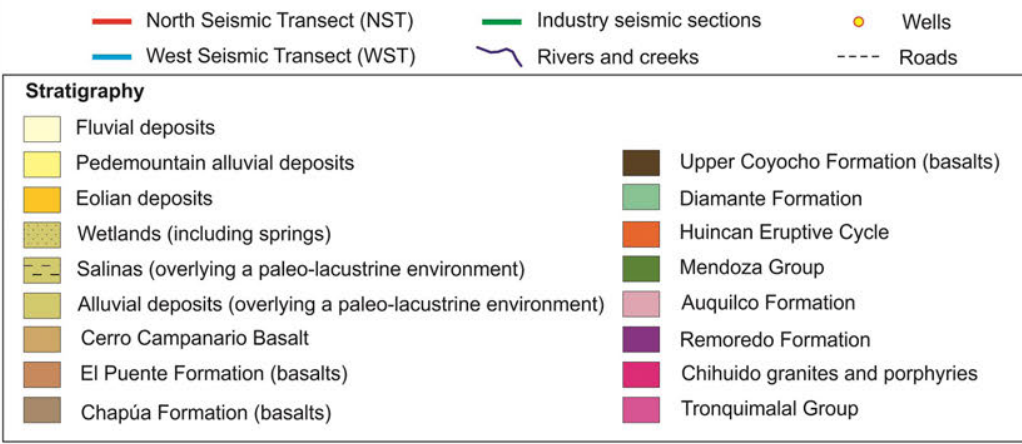

FIG. 1. a. Location map with the main regional geomorphological environments of the Province of Mendoza (from Violante et al., 2010). The rectangle delimits the studied zone; b. Geological map of the studied zone (modified after de la Vega et al., 2012). Location of seismic profiles (lines 09090, 09108 and UN-81-110) and wells, from industry data base, are shown. Lines Sis1, Sis2, N1, N2 and Sis3 to Sis7, corresponding to the north seismic transect (NST-in red) and lines W1 to W4 corresponding to the west seismic transect (WST- in blue), are also shown. 
ranging between $500 \mathrm{~m}$ in the Malargüe basin and $1,000 \mathrm{~m}$ in the Llancanelo lake area. The Llancanelo and Payenia Volcanic Fields that surround the lake contain very extensive basaltic lava flows formed since Pliocene times, which conditioned most of the late stages of the regional evolution. Several volcanic units outcrop in the area (Fig. 1b). The tectonic, volcanic and geomorphological context, added to the conditions imposed by the Quaternary climatic changes, made the Llancanelo Lake area (Llancanelo Sub-basin) to behave as a depocenter in which the sedimentary and volcanic sequences resulting from different intra and extra basinal processes preserve the records of the evolutionary history of the region (Violante et al., 2010; Rovere et al., 2010, 2012; De la Vega et al., 2012; Osella et al., 2015). The geometry of the lacustrine depocenter is markedly asymmetric, with its eastern side being an abrupt feature limiting with the San Rafael Block, whereas its western side is gentle, in a transition to the area where the Malargüe Thrust and Fold Belt extends.

The regional stratigraphy is synthesized after Nullo et al. (2005) and displayed in figure 2. Three marine cycles alternating with continental sequences are recognized since the Jurassic. Marine sequences are Molles Formation (Jurassic: Liasic-Dogger), Mendoza Group (Tithonian-Albian) and Malargüe Group (Maastrichtian-Danian). Continental sequences in between are Tordillo Formation (Kimmeridgian) and Neuquén Group (Upper Cretaceous). The last marine transgression is represented by a typical regressive sequence (Malargüe Group). It is followed by sedimentary volcanic sequences responding to the major development of the active Cenozoic volcanism, with at least 9 basaltic sequences in the stratigraphic column (Nullo et al., 2005). In the Llancanelo lake surroundings, most of the Cenozoic units reach its full expression and crop out (Fig. 1b), whereas the pre-Cenozoic units extend only in the subsoil.

\section{Seismic data sources}

Two main sources of data are utilized in the present contribution. Deep seismic and stratigraphic (oil wells) information was available from the industry (Urien and Associates, 2014'), while shallow seismic reflection data was acquired by our research group.

The industry data affords an adequate regional chrono-, seismic- and litho-stratigraphic framework which is essential for correlating and interpreting

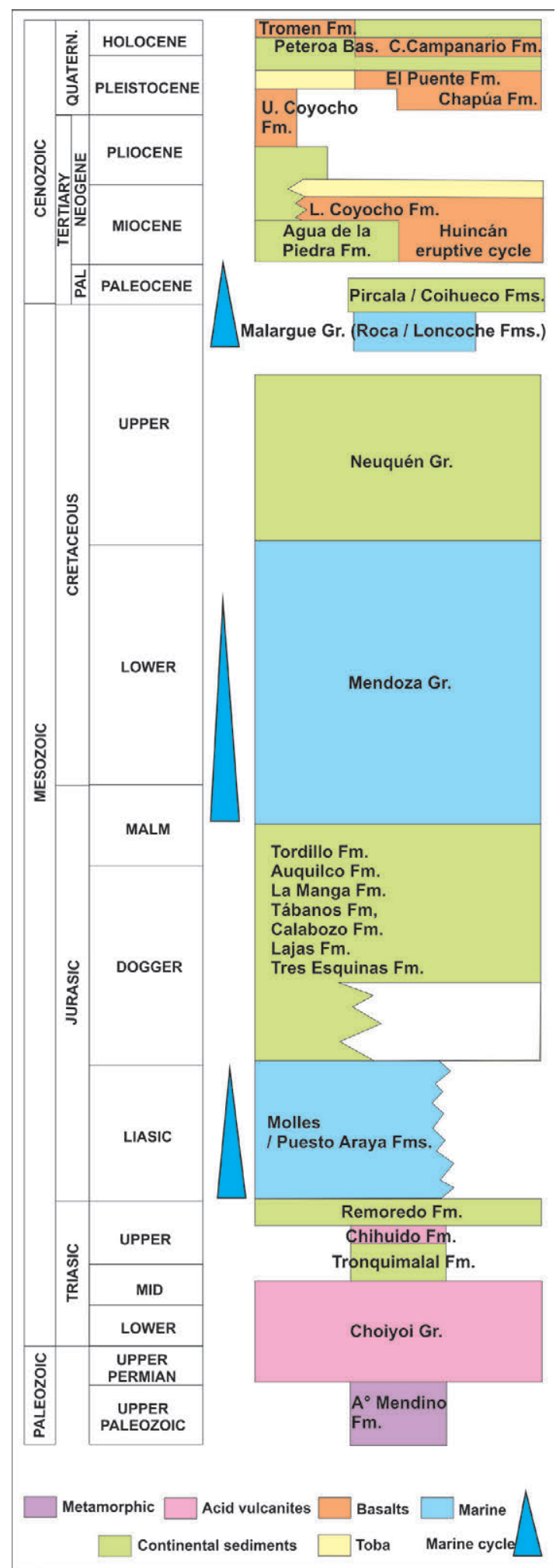

FIG. 2. Regional stratigraphic scheme (from Nullo et al., 2005). 
the local seismic stratigraphic sequences arising from our own seismic data. Regarding the latter, it includes new seismic surveys conducted around the lake which significantly extend and complement the results of a previous work (Osella et al., 2015).

\subsection{Oil prospecting seismic data}

Three industry seismic sections were available for its interpretation (shown in figure 1b). North of the lake is seismic line 09090, which contains wells $\mathrm{CH} 2, \mathrm{CH} 1, \mathrm{LiP} 1, \mathrm{LiP} 5$ and LiP2.

West of the lake there are two lines: line 09108 west of Trapal volcano, and line UN-81-110 that represents a continuation of the other to the northeast, going along the northern part of the Trapal volcano and crossing the Malargüe river close to its outlet in the lake. On the track of line 09108 there are two oil wells, CHi1 and LL1, whereas on line UN-81-110 several wells located few kilometres to the south can be projected, such as wells LLe5, LLe11, LLe7, LLa13 and LLa10.

These seismic sections do not cross the very depocenter of the Llancanelo basin, but are instead located to the west in areas where the industry interest undoubtedly pursued targets other than scientific research. However, their interpretation in the framework of the ongoing research enabled to compose a more complete regional geological picture and provided new information to improve the interpretation of our data. The available lithostratigraphic information arises from the above mentioned wells included in the seismic lines, which provide broad descriptions of the lithostratigraphic units.

\subsection{Shallow seismic data}

The new seismic surveys were conducted around the lake, filling gaps and extending laterally the study on the east-to-west-oriented transects surveyed in our previous works (one transect to the north and the other one to the west of the lake, Fig. 1b). As a result, it was possible to double the number of lines and kilometres covered by the study.

The transect located to the north of the lake (north seismic transect, herein identified as NST) crosses perpendicularly through the northward prolongation of the main depocenter of the lacustrine basin from west to east even reaching its eastern (abrupt) side. This line extends to the east of seismic line 09090 (leaving a gap of 3,800 m) and therefore allows compiling a fairly complete seismic section crossing most of the lake basin.

Transect NST is composed of three sections crossing the central part of the lacustrine basin north of Llancanelo lake. The two external sections were preliminarily interpreted in a previous paper (Osella et al., 2015), and include lines Sis1 and Sis2 at the western end and lines Sis 3 to Sis 7 at the eastern end (Fig. 1b). For the objectives of the present contribution, and in order to fill the gap between them, a new section (N1-N2) was surveyed, so completing a fairly continuous and uninterrupted profile $16 \mathrm{~km}$ long. The section N1-N2 is located right at the northern extension of central part of Llancanelo lake, so it is thought that it could represent the basin depocenter. The segments comprised by Sis1-Sis2 and N1-N2 are 2,300 $\mathrm{m}$ and 2,700 $\mathrm{m}$ long, while Sis3-Sis7 span a 5,200 m segment. This leaves some short gaps in between (the gaps between sectors are 2,200 and $3,900 \mathrm{~m}$ long, respectively). Their disposition (three sections with gaps instead of one continuous section) was forced in order to avoid surveying in parts of the road with significant bends and irregularities in their path. However, the previous preliminary results showed uniformity in the sedimentary structures following the regional stratigraphic trend, and therefore the presence of gaps is considered to be not important for further geological correlations and interpretations. Transect NST complements line 09090 surveyed by the industry as represents a continuation of this one to the east reaching the eastern border of the Llancanelo basin. Towards the west, line 09090 extends around $30 \mathrm{~km}$ kilometres and therefore it allows covering most of the Llancanelo basin.

The transect located to the west of the lake (west seismic transect, herein identified as WST) was surveyed immediately west of the lakeshore, also with the objective of extending the original seismic transect from previous works. In this way a transect $4.5 \mathrm{~km}$ long along the western (gentle) side of the lake was obtained, which comprises lines W1 to W4 (Fig. 1b). It complements section 09108 available from the industry which extends around $30 \mathrm{~km}$ to the west, and is parallel to UN-81-110 and comparable with it with respect to their relative position in the basin.

As a result, a fairly complete section of a large part of the lacustrine basin (Llancanelo sub-basin) could be obtained by combining in both transects our own data (the new ones and those surveyed during 
previous studies), together with regional seismic and lithostratigraphic schemes provided by the industry.

The new profiles were acquired with 96-fixed receivers and 10 meter separation between them, using a Gisco ESS 100 electrically operated seismic source with 2 or 3 -fold stacking. The acquisition was performed with a Geode Geometric DZ device and using Seismodule Controller 9.1 software. Recording time varied from line to line up to a maximum of 1.0 second, with a constant $4,000 \mathrm{~Hz}$ sampling rate.

The methodology followed for data processing has been widely described in a previous work (Osella et al., 2015).

Final stack sections, including previous data, are shown in figure $3 \mathrm{a}$ and $\mathrm{b}$, for NST and WST, respectively.
Along NST there are three main seismic reflectors with good lateral continuity, and high relative amplitudes. A shallow reflector (red curve in figure 3a) is clearly recognizable along each of the 9 lines of the transect. It is associated with stacking velocities of 1,500-1,700 m/s, and a depth of nearly $50 \mathrm{~m}$ on the easternmost line (Sis7), deepening to $150 \mathrm{~m}$ towards the west (Sis1). The middle reflector (blue curve in figure $3 a$ ) is clearly identified up to the two last eastern lines. Finally, a deeper reflector (green curve in figure $3 a$ ) is also clearly recognizable along the five easternmost lines, and though less clear in lines N1, N2 and Sis2, the slope of the last sharp horizon seen on line Sis1 matches its projected slope. If indeed it is the same reflector, it deepens westward from $400 \mathrm{~m}$ to $750 \mathrm{~m}$.
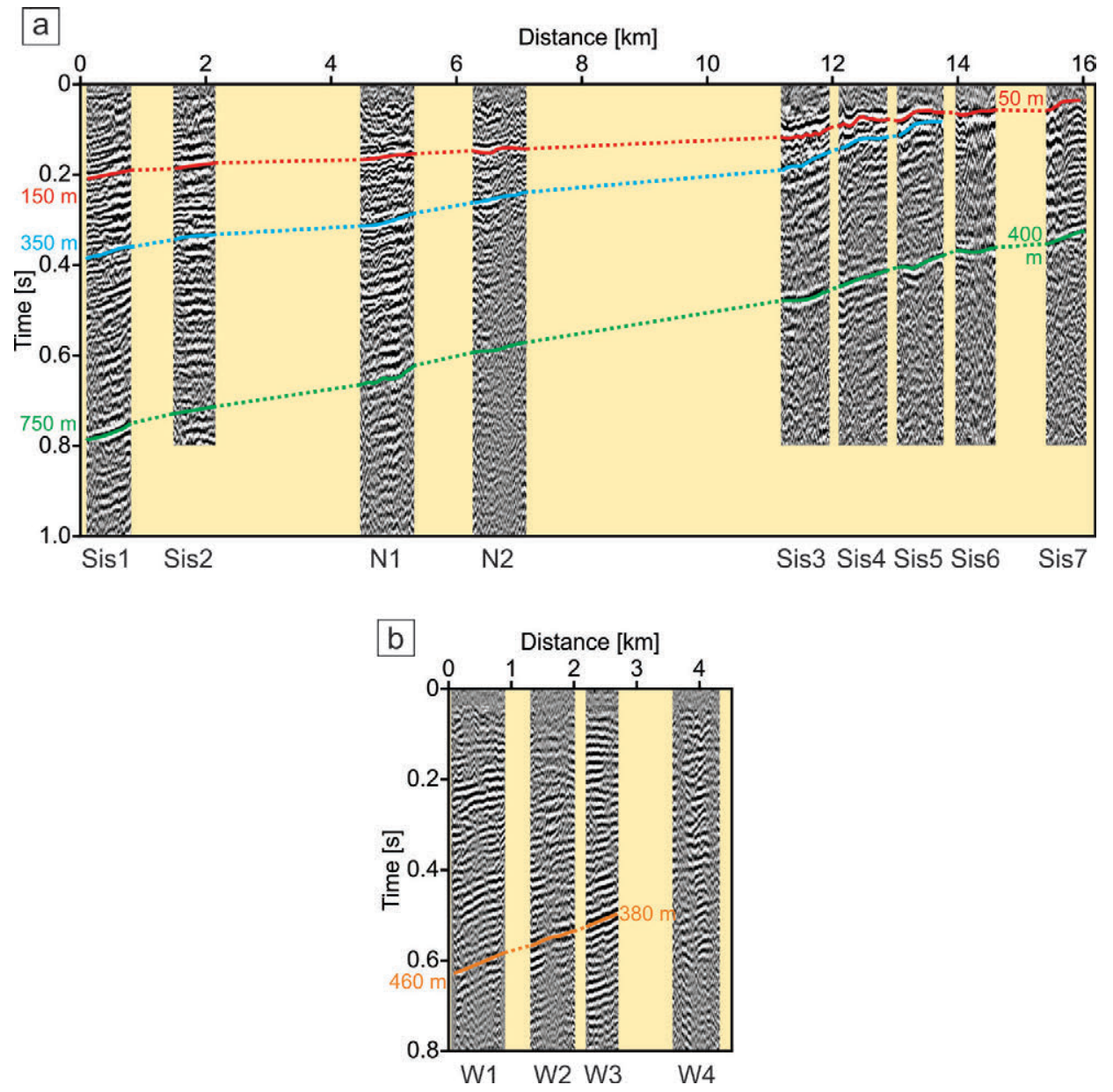

FIG. 3. Final stacked sections, including previous data, for a. NST, and b. WST, respectively. Full lines indicate the main seismic discontinuities. 
Horizons with lateral continuity are also recognized along the 3 westernmost lines of WST. Unlike NST, where the same two horizons have the highest relative signal levels across all lines, the processing of WST yielded uneven amplitudes. For instance, the most clearly defined event on $\mathrm{W} 3$ is recognizable in $\mathrm{W} 1$ and $\mathrm{W} 2$, but its relative amplitude is much lower.

\section{Seismic data interpretation}

\subsection{Reinterpretation of the industry seismic sections}

The industry seismic records and oil wells compose two east-west sections, respectively north and west of Llancanelo Lake (Fig. 1b). The seismic sections show at a regional scale a stratified structure dipping to the west in direction to the Malargüe fold and thrust belt.
The northern section (Fig. 4a) shows a regional structure of parallel to quasi-parallel reflectors, regionally dipping to the west. However, dipping angles increase progressively with depth, being the layering above $\sim 0.5 \mathrm{~s}$ nearly subhorizontal. Several conspicuous seismic reflectors are evident. A major strong reflector in the deeper sections is SR1 (Fig. 4a), which according to the regional lithostratigraphy and the preliminary correlations from the industry included in the seismic profile represents a regional unconformity at the top of Roca Formation. This unconformity is characterized by an erosive surface with toplap reflections. Below the seismic reflector a lower depositional sequence (LDS) develops, which shows in the upper section layers dipping to the west in concordance with the regional structure. This sequence contains the marine units interbedded with continental deposits described
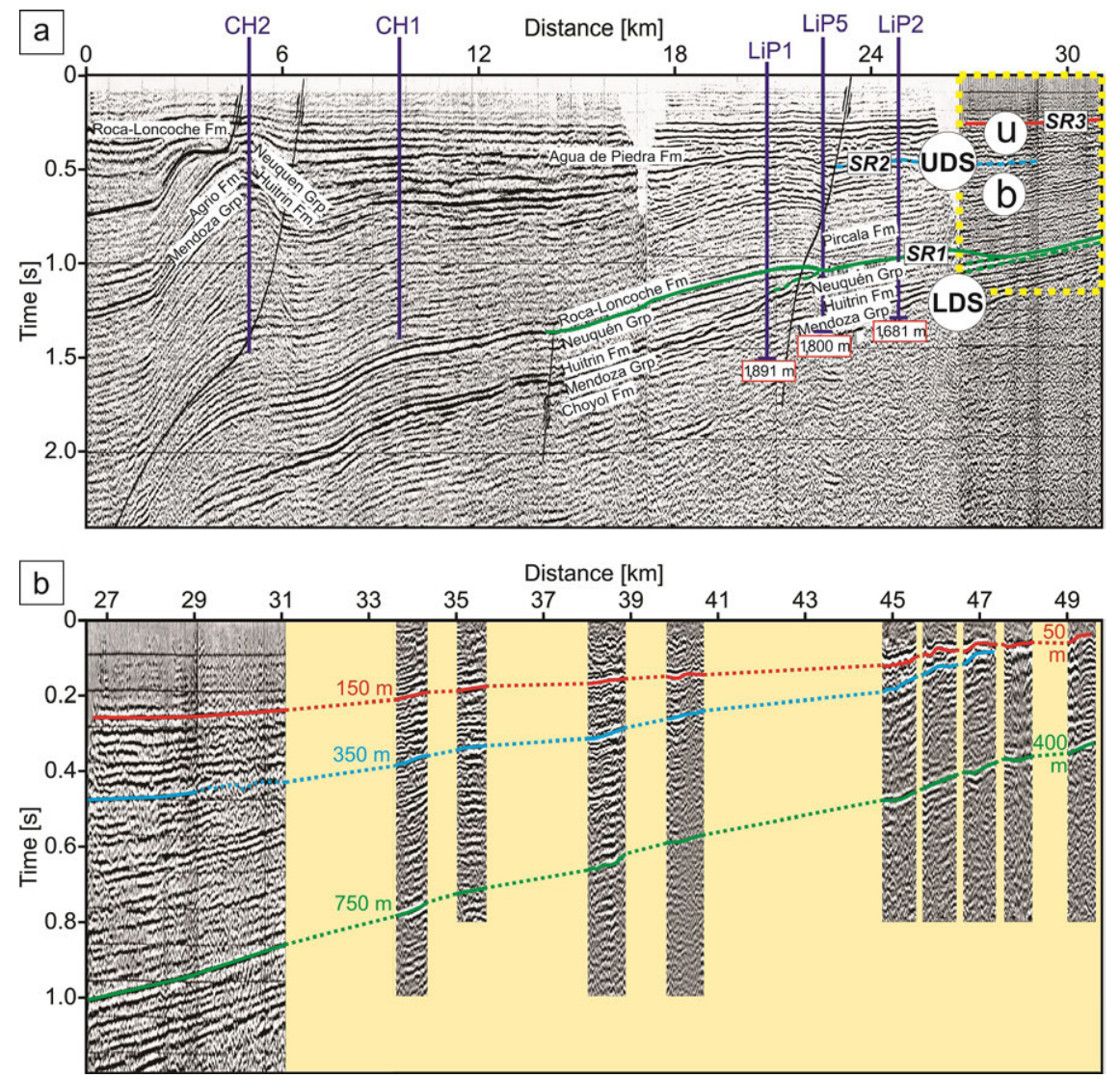

FIG. 4. a. Seismic profile corresponding to line 09090 . Wells used for identifying seismic units are indicated. The box delimited with dashed lines corresponds to the sector used for correlating to NST; b. Correlation between the east end of line 09090 (indicated in a) as a dashed box) and NST (from figure 3a). Main seismic reflectors, SR1, SR2 and SR3 are shown in the figures. 
by Nullo et al. (2005) that end at its top with the Roca-Loncoche Formation that represents the final cycle of the Malargüe Group; this sequence shows internal seismic reflectors of high intensity. Above SR1, starting with Pircala Formation (a continental sedimentary sequence with some marine influence), an upper continental depositional sequence (UDS) develops, which according to the stratigraphy known for the region is characterized by a succession of basaltic layers associated to the occurrence of intense volcanic activity that dominated in the region since the Danian-Miocene. The upper sequence UDS shows aggrading units with internal reflectors of less intensity that those characterizing the LDS. Reflector SR1 separating the Cretaceous sequence LDS -dominantly marine- from the Cenozoic sequence UDS -dominantly basaltic- is at a depth between 1,000-1,200 ms in the eastern sector close to the sections surveyed for this research, slightly shallowing to the east.

The upper sequence UDS can be subdivided into two subunits separated by seismic reflector SR2 (in blue): a basal (UDSb) section with reflectors of less intensity, and an upper section (UDSu) showing more intense reflectors. UDSu, composed of parallel and mainly subhorizontal layers, could be correlated with the stratigraphic sequence that initiates with Agua de la Piedra Formation, deposited in an alluvial fan environment in the lower Miocene (according to Nullo et al., 2005). This Formation is herein considered as representing the base of the continental conditions that were installed in the region since those times, accompanied by the development of a volcanic cycle represented by basaltic sequences. Discontinuity SR2 is at a depth between 450 and $550 \mathrm{~ms}$ shallowing to the east. An uppermost reflector, named SR3, is recognized in the middle part of Unit UDSu. Although in the industry information the "very upper" sequences are not clearly recorded because the used seismic method has very low resolution in the sections of no hydrocarbon interest, according to the known stratigraphy of the region and the previous conclusions by De la Vega et al. (2012) and Osella et al. (2015), SR3 could be preliminary assigned to a horizon close to the base of the Chapúa Formation (base of the Quaternary basaltic successions).

The southern section (Fig. 5a), west of the lake and close to Trapal volcano, is more difficult for interpreting the regional stratigraphy. The presence of a possible fault between wells LLa10 y LLa13 distortions the layers succession, whereas on the other hand, the uppermost sequences possibly related to UDS lose individuality eastward, and details of their disposition are not possible to observe in the right side of figure 5a. It is interpreted that the masking of the seismic structure in that sector could also be associated to the presence of very soft sediments as those proper of the lacustrine succession close to the very depocenter of the lacustrine basin. It can be concluded for this section that the horizon identified as "Basalt" in the industry seismic would correspond to the discontinuity between LDS and UDS, so indicating the transition from the lower marine to the upper continental layers. As observed in figure $5 \mathrm{a}$, if the seismic line is extended to the northeast through line UN-81-110, the strong reflectors identified as "basalts" seem to extend in that direction, what is also documented by the lithological descriptions of wells LLe7, LLa10 and LLe11.

\subsection{Stratigraphic information from the industry}

Although detailed lithological information from the industry wells was not available, the general descriptions (Urien and Associates, 2014) show marked differences at the top of the wells in the levels at the depths of our seismic data, when comparing those wells located north of Llancanelo lake with those at the west of the lake. Wells along transect NST begun with an upper sedimentary (continental to marine) unit, Pircala-Coihueco Formation, having a maximum thickness up to $\sim 1,200 \mathrm{~m}$. Instead, wells along transect WST are topped by several hundred of meters thick Pleistocene basaltic sequences, what is coherent with the surface geology that shows in the region a predominance of outcrops of basaltic units (Fig. 1). Both Pircala-Coihueco and the basalts are underlain by a regionally extended unit, RocaLoncoche Formation representing the final stages of a marine transgression (Malargue Group). Since Pircala-Coihueco and the Pleistocene basalts are not of hydrocarbon interest, no more detailed lithological information is provided by the general descriptions of the industry wells.

\subsection{Interpretation of the surveyed seismic sections}

Our seismic sections comprise, as stated above, the seismic sections surveyed by Osella et al. (2015) 

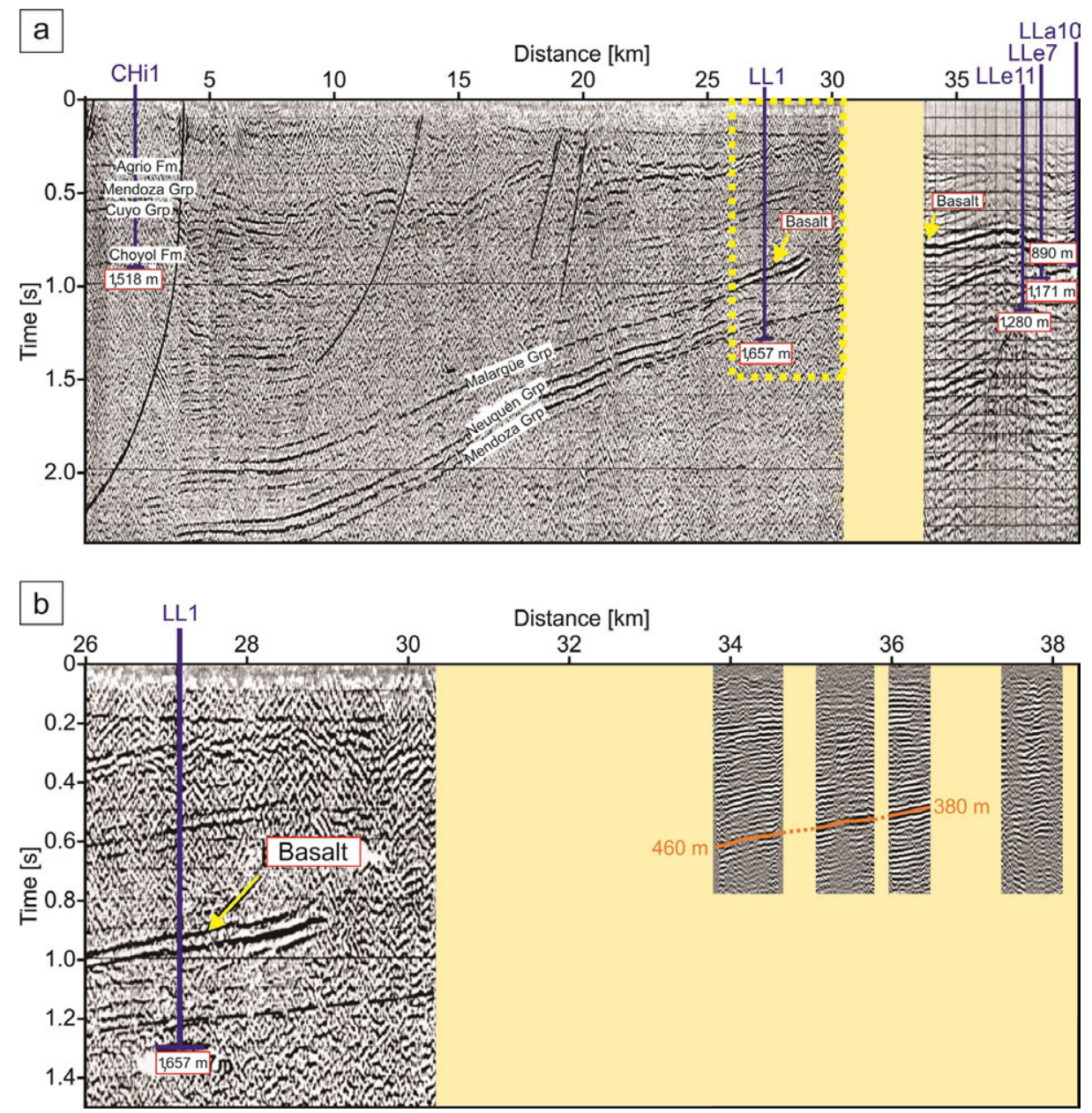

FIG. 5. a. Seismic profiles corresponding to lines 09108 and UN-81-110. Wells used for identifying seismic units in these lines are indicated. The box delimited with dashed lines corresponds to the sector used for correlating to WST; b. Correlation between the east end of line 09108 (indicated in a) as a dashed box) and WST (from figure 3b).

plus new lines that enabled to double the data-base and to complete more continuous sections. These lines were correlated with the industry lines, and as a result of this the compiled sections represented in figures $4 \mathrm{~b}$ and $5 \mathrm{~b}$ were constructed, respectively for the NST and WST. On the other hand, a stratigraphic correlation was made between the stratigraphic units defined by the application of different geophysical methods (Fig. 6), such as those resulted from geoelectric methods (De la Vega et al., 2012), shallow seismic (Osella et al., 2015) and deep seismic from the industry.

The herein described upper sequence UDS includes the previously described sequences by
Osella et al. (2015) composed of three units: upper -UU-, middle -MU- and lower -LU-. Based on the seismic from the industry and the lithological descriptions of oil wells (Urien and Associates, 2014) which are shown in figure $1 b$, UU is postPliocene and has a composition mainly basaltic with intercalation of sedimentary layers. MU and LU are pre-Pliocene and have similar characteristics, although the seismic properties indicate a decreasing of basaltic layers with depth, compatible with the available lithological information. The lithological characteristics of UDS, according to the correlation with the information provided by the oil wells and the lithological descriptions of stratigraphic units by 
De la Vega et al., 2012

ULU Upper lacustrine Unit
UBU Upper Basaltic Unit
Cerro Campanario Basalt
LSU Lower sedimentary Unit
LBU Lower Basaltic Unit
= Chapúa Fm. (Plio-Pleist).

\section{Osella et al., 2015}

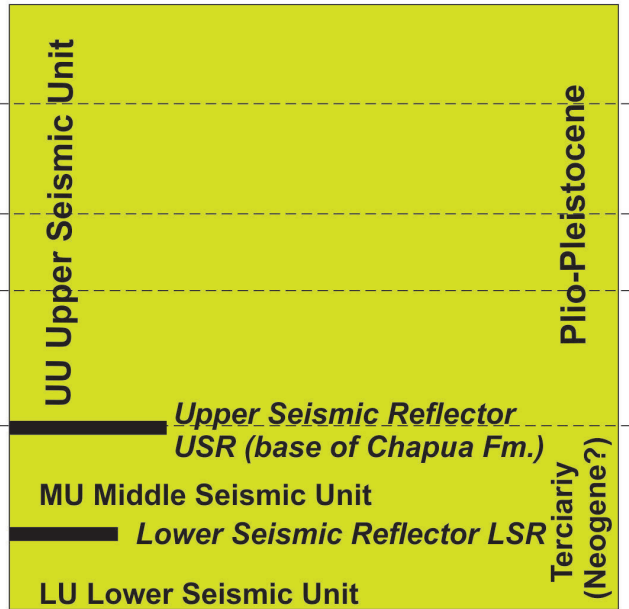

LU Lower Seismic Unit
Industry seismic sections

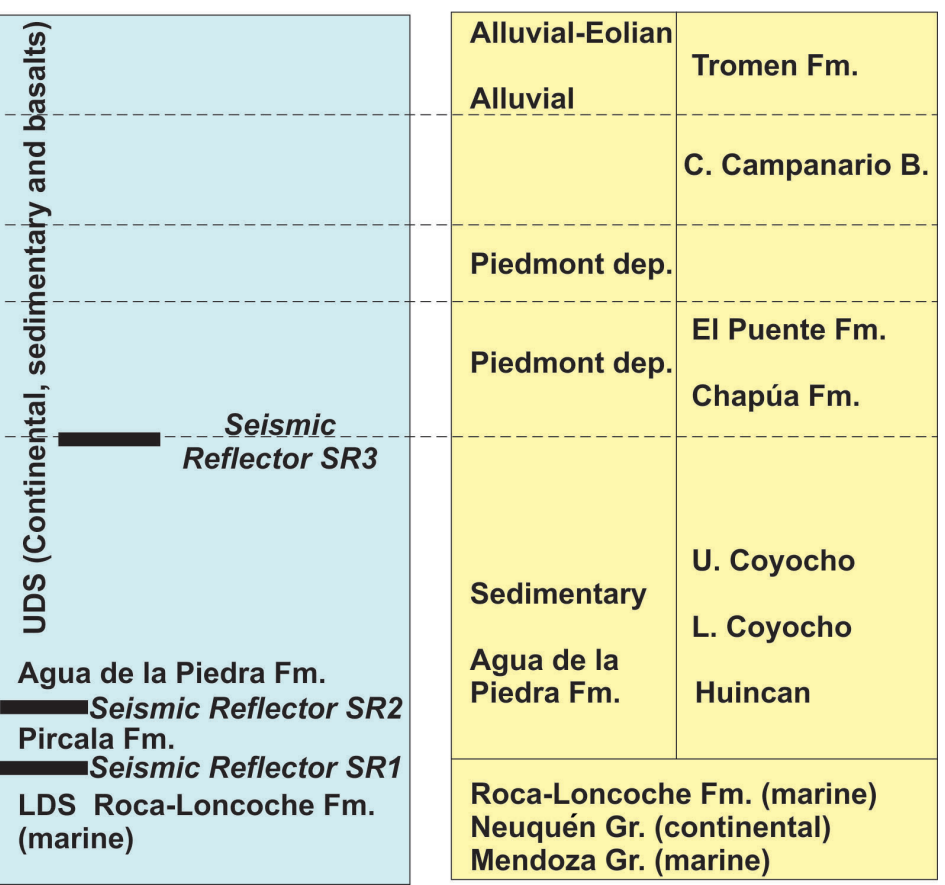

FIG. 6. Correlation between the stratigraphic units defined from the application of geoelectric methods (De la Vega et al., 2012), shallow seismic (Osella et al., 2015 and present results), deep seismic from the oil prospecting (Urien and Associates, 2014), and the stratigraphic regional synthesis (adapted from Nullo et al., 2005). 
Nullo et al. (2005), seem to confirm the decreasing of basaltic layers with depth, as evidenced by the presence, in the lower part of the sequence, of Miocene lithostratigraphic units with a sedimentary filiation rather than a volcanic filiation (Pircala and Agua de la Piedra Formations) (Fig. 2). In this sense, UDS herein described -limited at its base by seismic reflector SR1- comprises the Cenozoic sequence composed of continental deposits represented by intercalation of sedimentary and volcanic units. Seismic reflector SR2 separates the UDS unit in two parts, the lower one representing the Pircala Formation of Paleocene age, and the upper one representing the post-Miocene dominantly volcanic sequence that begins with the Huincan eruptive cycle contemporaneous with the sedimentary Agua de la Piedra Formation.

Most of the sequences surveyed by the performed shallow seismic correspond to the UDS, as reflector $\mathrm{SR} 1$ is close to the maximum registration depth $(750 \mathrm{~m})$. Instead, reflector SR2 was well recorded by the applied method at a maximum depth of $350 \mathrm{~m}$. Both reflectors rapidly decrease in depth to the east, in the direction of the basin border where the uppermost basaltic sequences crop out (Violante et al., 2010; De la Vega et al., 2012).

The sequence LDS is below the penetration depth of the shallow seismic, so it was recognized only in the deep industry seismic. It corresponds to the Mesozoic units according to Nullo et al. (2005), representing several marine cycles.

At the present stage of this study, from shallow seismic and near-surface geophysics data and after the compilation of our own and industry information, we couldn't find further evidence of the north-tosouth trending fault limiting the Llancanelo lake basin at its eastern border, as it was considered by Ramos (1999), Ramos and Folguera $(2005,2011)$ and Folguera et al. (2008).

\section{Conclusions}

Considering the results contained in the present contribution and previous information obtained by our research team, the following conclusions can be summarized:

a. The applied shallow seismic method enabled to depict a seismic stratigraphic scheme up to a depth of $750 \mathrm{~m}$ for the region of Llancanelo Lake. The obtained scheme was correlated with deep seismic obtained from the industry, and the whole stratigraphic picture was interpreted on the basis of the well know regional stratigraphy. The obtained results represent a significant advance in relation to previous works performed in the region.

b. Three major seismic horizons were recognized, from base to top: SR1 representing the termination of the Mesozoic marine cycles and the beginning of the pure continental conditions in the region. SR2 representing the beginning of the Cenozoic basaltic volcanism. SR3 seismic horizon representing the beginning of the dominant volcanic conditions at the base of the Quaternary.

c. The resulting scheme shows that tectonism did not seem to play a relevant role in the configuration of the lacustrine basin, at least since the late Mesozoic and during the Cenozoic.

d. This contribution provides new information about the major factors involved in the regional evolution during the last stages of the Mesozoic and in the Cenozoic, and confirms the preliminary results arising from previous research in the region. In the Mesozoic, clastic sedimentation associated to alternating marine and continental cycles was the dominant process. In the Cenozoic, under an exclusively continental sedimentation, volcanism begun to force the regional evolution and during the Quaternary reached its maximum development, being the main processes that conditioned the final evolution of the lacustrine basin.

\section{Acknowledgments}

This work was partially supported by grants from Agencia Nacional de Promoción Científica y Tecnológica, PICT 2011/1268 and PICT 2014/1613. Authors deeply thank Dr. C.M. Urien (Urien and Associates-U and A, Buenos Aires), who kindly provided the industry seismic lines and oil wells descriptions.

\section{References}

Bermúdez, A.; Delpino, D.H. 1989. La Provincia Basáltica Andino Cuyana $\left(35-37^{\circ} \mathrm{S}\right)$. Revista de la Asociación Geológica Argentina 44 (1-4): 35-55.

Cortés, J.M.; Vinciguerra, P.; Yamin, M.; Pasini, M.A. 1999. Tectónica Cuaternaria de la región andina del Nuevo

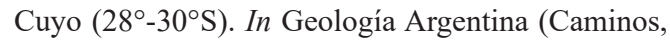
R.; editors), Servicio Geológico Minero Argentino, Anales: 760-778.

De la Vega, M.; López, E.; Osella, A.; Rovere, E.I.; Violante, R.A. 2012. Quaternary volcanic-sedimentary 
sequences and evolution of the Llancanelo Lake región (Southern Mendoza, Western Argentina) evidenced from geoelectric methods. Journal of South American Earth Science 40: 116-128.

Folguera, A.; Bottesi, G.; Zapata, T.; Ramos, V.A. 2008. Crustal collapse in the Andean back-arc since $2 \mathrm{Ma}$ Tromen volcanic plateau, Southern Central Andes (36²'-37³0’S). Tectonophysics (Special Issue Andean Geodynamics) 459: 140-160.

Llambías, E.J.; Bertotto, G.W.; Risso, C.; Hernando, I. 2010. El volcanismo cuaternario en el retroarco de Payenia: una revisión. Revista de la Asociación Geológica Argentina 67 (2): 278-300.

Nullo, F.; Stephens, G.; Combina, A.; Dimitri, L.; Baldauf, P.; Bouza, P. 2005. Hoja Geológica 3569-III/3572-IV “Malargüe". Servicio Geológico Minero Argentino, Boletín 346: 85 p.

Osella, A.; Onnis, L.; De la Vega, M.; Tassone, A.; Violante, R.A.; Lippai, H.; López, E.; Rovere, I.E. 2015. Seismic reflection survey at Llancanelo region (Mendoza, Argentina) and preliminary interpretation of Neogene stratigraphic features. Journal of South American Earth Sciences 60: 71-81.

Ostera, H.; Dapeña, C. 2003. Environmental isotopes and geochemistry of Bañado Carilauquen, Mendoza, Argentina. In South American Symposium on Isotope, No. 4, Geology, Short Papers: 461-464. Salvador.

Polanski, J. 1963. Estratigrafía, neotectónica y geomorfología del Pleistoceno pedemontado, entre los ríos Diamante y Mendoza. Revista de la Asociación Geológica Argentina 17 (3-4) (1962): 127-349. Buenos Aires.

Ramos, V.A. 1999. Las provincias geológicas del territorio argentino. In Geología Argentina, Secretaría de Minería de la Nación (Caminos, R.; editor), Servicio Geológico
Minero Argentino, Instituto de Geología y Recursos Minerales, Anales 2: 41-96.

Ramos, V.A.; Folguera, A. 2005. Structural and magmatic responses to steepening of a flat subduction, southern Mendoza, Argentina. In International Symposium on Andean, No. 6, Geodynamics (ISAG 2005 Barcelona, Spain): 592-595.

Ramos, V.A.; Kay, S.M. 2009. Overview of the tectonic evolution of the southern Central Andes of Mendoza and Neuquén (35-39 $\mathrm{S}$ latitude). In Evolution of an Andean Margin: a Tectonic and Magmatic View from the Andes to the Neuquén Basin (35-39 ${ }^{\circ} \mathrm{S}$ Lat.) (Kay, S.M.; Ramos, V.A.; editors). Geological Society of America, Special Paper 407: 1-17.

Ramos, V.A.; Folguera, A. 2011. Payenia volcanic province in the Southern Andes: An appraisal of an exceptional Quaternary tectonic setting. Journal of Volcanology and Geothermal Research 201: 53-64.

Rovere, E.I.; Violante, R.A.; Osella, A.; De la Vega, M.; López, E. 2010. Reconstruction of the evolutive stages of Llancanelo Lake and surroundings (Southern Mendoza province, Western Argentina). GeoSur 2010 Bollettino Geofisica 51: 196-198.

Rovere, E.I.; Violante, R.A.; Rodríguez, E.; Osella, A.; De la Vega, M. 2012. Aspectos tefrológicos de los depositos volcánicos de la erupción del Volcán Quizapú de 1932 en la región de la Laguna Llancanelo, Payenia (Mendoza, Argentina). Latin American Journal of Sedimentology and Basin Analysis 19 (2): 125-149.

Violante, R.A.; Osella, A.; de la Vega, M.; Rovere, E.I.; Osterrieth, M.L. 2010. Paleoenvironmental reconstruction in the western lacustrine plain of Llancanelo Lake, Mendoza. Journal of South American Earth Sciences 29: 650-664.

Manuscript received: December 29, 2016; revised/accepted: August 2, 2017; available online: October 2, 2017.

Editorial handling: Gonzalo Yáñez. 